\title{
Aggregated Recombinant Human Interferon Beta Induces Antibodies but No Memory in Immune-Tolerant Transgenic Mice
}

\author{
Miranda M. C. van Beers $•$ Melody Sauerborn $•$ Francesca Gilli $•$ Vera Brinks $•$ Huub Schellekens $•$ Wim Jiskoot
}

Received: 3 March 2010 / Accepted: 10 May 2010 / Published online: 25 May 2010

(C) The Author(s) 2010. This article is published with open access at Springerlink.com

\begin{abstract}
Purpose To study the influence of protein aggregation on the immunogenicity of recombinant human interferon beta (rhIFN $\beta$ ) in wild-type mice and transgenic, immune-tolerant mice, and to evaluate the induction of immunological memory. Methods RhIFN $\beta$ - I $b$ and three rhIFN $\beta$ - Ia preparations with different aggregate levels were injected intraperitoneally in mice $15 \times$ during 3 weeks, and the mice were rechallenged with rhIFN $\beta$ - Ia. The formation of binding (BABs) and neutralizing antibodies (NABs) was monitored.

Results Bulk rhIFN $\beta$ - I a contained large, mainly non-covalent aggregates and stressed rhIFN $\beta$ - I a mainly covalent, homogeneous (ca. $100 \mathrm{~nm}$ ) aggregates. Reformulated rhIFN $\beta$ - I a was essentially aggregate-free. All products induced BABs and $\mathrm{NABs}$ in wild-type mice. Immunogenicity in the transgenic mice was product dependent. RhIFN $\beta$ - I b showed the highest and reformulated rhIFN $\beta$ - Ia the lowest immunogenicity. In contrast with wild-type mice, transgenic mice did not show $\mathrm{NABs}$, nor did they respond to the rechallenge.
\end{abstract}

M. M. C. van Beers • M. Sauerborn • V. Brinks $\cdot$ H. Schellekens

Department of Pharmaceutics

Utrecht Institute for Pharmaceutical Sciences (UIPS)

Utrecht University

Utrecht, The Netherlands

M. M. C. van Beers $(\bowtie) \cdot$ W. Jiskoot

Division of Drug Delivery Technology

Leiden/Amsterdam Centre for Drug Research (LACDR)

Leiden University

Einsteinweg 55

2333 CC Leiden, The Netherlands

e-mail: m.m.c.vanbeers@lacdr.leidenuniv.nl

F. Gilli

Regional Centre for Multiple Sclerosis (CReSM) and Clinical

Neurobiology, AOU S. Luigi Gonzaga

Orbassano (TO), Italy
Conclusions The immunogenicity of the products in transgenic mice, unlike in wild-type mice, varied. In the transgenic mice, neither $N A B s$ nor immunological memory developed. The immunogenicity of rhIFN $\beta$ in a model reflecting the human immune system depends on the presence and the characteristics of aggregates.

KEY WORDS antibodies · immunogenicity · immunological memory p protein aggregates $\cdot$ recombinant human interferon beta

\begin{tabular}{|c|c|}
\hline \multicolumn{2}{|c|}{ ABBREVIATIONS } \\
\hline BABs & binding antibodies \\
\hline ECD & equivalent circular diameter \\
\hline hIFN $\beta$ & human interferon $\beta$ \\
\hline HSA & human serum albumin \\
\hline $\lg G$ & immunoglobulin G \\
\hline i.p. & intraperitoneally \\
\hline MXA & myxovirus resistant protein $\mathrm{A}$ \\
\hline NABs & neutralizing antibodies \\
\hline PDI & polydispersity index \\
\hline $\operatorname{rhlFN} \beta$ & recombinant human interferon beta \\
\hline $\operatorname{rhIFN\beta -Ia}$ & recombinant human interferon beta- Ia \\
\hline rhIFN $\beta-I b$ & recombinant human interferon beta- $\mathrm{Ib}$ \\
\hline RR-MS & relapsing-remitting multiple sclerosis \\
\hline SDS & sodium dodecyl sulfate \\
\hline $\mathrm{TRU} / \mathrm{ml}$ & ten-fold reduction units per $\mathrm{ml}$ \\
\hline
\end{tabular}

\section{INTRODUCTION}

The ability of biopharmaceuticals to elicit an undesirable immune response in patients is a major concern. Despite the development of recombinant therapeutic homologues to 
human proteins, antibodies are still frequently observed in patients $(1,2)$. In general, antibodies against recombinant human therapeutic products only appear after prolonged treatment. They can have an effect on the clearance of the drug, decrease its therapeutic efficacy, or may lead to immune complex-related diseases such as anaphylaxis and serum sickness (3). Occasionally, antibodies cross-react with the endogenous homologous protein, leading to severe clinical consequences, e.g. in the case of epoetin (4). An example of a therapeutic protein with high clinical immunogenicity is recombinant human interferon beta-1b (rhIFN $\beta-1 b)$.

The rhIFN $\beta$ s are considered first-line disease-modifying therapies of relapsing-remitting forms of multiple sclerosis. They reduce relapse rates and brain lesions. A substantial proportion of relapsing-remitting multiple sclerosis (RR-MS) patients shows a decline in response over time, which can be attributed to the formation of neutralizing antibodies (NABs). This immunological response generally starts with the appearance of BABs after approximately 9 to 18 months of treatment, followed by NABs (5). Neutralizing antibodies against rhIFN $\beta$ are tested in assays based on the inhibition of a cellular response to human interferon beta.

All four commercial rhIFN $\beta$ products, Betaferon/ Betaseron ${ }^{\circledR}$ (Schering, Berlin, Germany and Berlex Laboratories, Montville, New Jersey, USA), Avonex® (Biogen Idec, Cambridge, Massachusetts, USA), Rebif® (Serono, Geneva, Switzerland) and Extavia ${ }^{\circledR}$ (Novartis, Basel, Switzerland), show immunogenicity in patients, but the level of BABs and NABs varies among the products (6). The products differ with respect to formulation, and route and frequency of administration. Moreover, Avonex ${ }^{\circledR}$ and Rebif ${ }^{\circledR}$ (both rhIFN $\beta$-la) are glycosylated, produced in $\mathrm{CHO}$ cells and have amino acid sequences corresponding to that of natural hIFN $\beta$, whereas Extavia ${ }^{\circledR}$ and Betaferon ${ }^{\circledR}$ (both $\operatorname{rhIFN} \beta-1 b$ ) are produced in $E$. coli, are not glycosylated and have a slightly different amino acid sequence (Cys-17 is mutated to Ser-17, and the N-terminal methionine is deleted (7)). These product differences apparently affect immunogenicity. Likely, the lower solubility due to the lack of glycosylation results in aggregation causing a high immunogenicity of $\mathrm{rhIFN} \beta-1 \mathrm{~b}(6,7)$. Whether the relatively low immunogenicity of rhIFN $\beta$-la products is also associated with aggregates is unknown.

Structure and formulation of the protein as well as degree of aggregation and aggregate characteristics are generally recognized as important factors influencing the immunogenicity of therapeutic proteins $(1,8,9)$. The immunogenicity of recombinant human interferon alpha was related to the level of aggregation (10). Also, clinical data with other therapeutic proteins, such as intravenous immune globulin, human growth hormone and interleukin-2, strongly suggest a direct correlation between aggregate levels and immunogenicity (11).
Transgenic, immune-tolerant mouse models are valuable tools to study the influence of product-related factors such as aggregation on immunogenicity $(8,12,13)$. Wild-type mice recognize recombinant human proteins as foreign and consequently exhibit a classical immune response. Mice transgenic for a specific human protein are, like humans, immune tolerant for this protein and provide the opportunity to study the factors that break immune tolerance. In addition, these mice enable us to study the immunological mechanism by which the antibodies to therapeutic proteins are induced. A classical immune response against a foreign protein leads to immunological memory, resulting in an enhanced response after rechallenge with that protein (14). Observations in patients producing antibodies to therapeutic proteins, who are retreated after a washout period, suggest a low level or even lack of memory response $(15,16)$.

In this work, rhIFN $\beta$-1a samples with different aggregate levels were prepared and characterized. The immunogenicity of these samples was compared with that of $\operatorname{rhIFN} \beta$ 1b. We tested immunogenicity by measuring $\mathrm{BAB}$ and NAB levels after repetitive administration and a rechallenge with rhIFN $\beta$-1a in our hybrid hIFN $\beta$ transgenic, immunetolerant mouse model (17). The aims of this study were to investigate the influence of aggregation on the immunogenicity of rhIFN $\beta$-la and to evaluate the formation of antibodies and the induction of immunological memory for the protein in wild-type mice and transgenic, immunetolerant mice.

\section{MATERIALS AND METHODS}

\section{RhIFN $\beta$ Products}

Bulk rhIFN $\beta$ - la was supplied by Biogen Idec Inc. (Cambridge, MA, USA) as a $0.27 \mathrm{mg} / \mathrm{ml}$ solution in $100 \mathrm{mM}$ sodium phosphate buffer and $200 \mathrm{mM}$ sodium chloride at $\mathrm{pH}$ 7.2. Reformulated rhIFN $\beta$-la was produced by dialysis of bulk rhIFN $\beta$-la with a 3.5 kDa MWCO Slide-A-Lyzer Cassette (Perbio Science, Etten-Leur, the Netherlands) against a commercially used formulation containing $20 \mathrm{mM}$ sodium acetate buffer, $150 \mathrm{mM}$ L-arginine monohydrochloride and $0.04 \mathrm{mM}$ Tween 20 (Sigma Aldrich, Zwijndrecht, the Netherlands) at pH 4.8 (18), and subsequent filtration through a $0.22 \mu \mathrm{m}$ polyethersulfone membrane (Millipore, Amsterdam, the Netherlands). The resulting protein concentration was determined by UV absorbance measurements at $\lambda=280 \mathrm{~nm}$ with an extinction coefficient $\left(\mathrm{E}_{0.1 \%}^{1 \mathrm{~cm}}\right)$ of 1.5 . This value was calculated from the molar mass of rhIFN $\beta-1$ a (20,027.78 Da) without carbohydrate chain and its molar extinction coefficient $\left(29,990 \mathrm{Lmol}^{-1} \mathrm{~cm}^{-1}\right)$ based on amino acid (Trp, Tyr, Phe and disulfide) composition (19). Biogen Idec Inc. supplied stressed rhIFN $\beta$-la produced by incubating 
$1.4 \mathrm{mg} / \mathrm{ml}$ monomeric rhIFN $\beta$ - $1 \mathrm{a}(<1 \%$ of aggregates) for one hour at $\mathrm{pH} 2.1$ in the presence of $1 \mathrm{M}$ sodium chloride. After incubation, the solution had been neutralized to $\mathrm{pH} 7.1$ and run over a Superose 12 size-exclusion column to isolate soluble aggregates. This resulted in $0.109 \mathrm{mg} / \mathrm{ml}$ stressed rhIFN $\beta$ - $1 \mathrm{a}$ in a buffer of $8 \mathrm{mM}$ dibasic sodium phosphate, $1.5 \mathrm{mM}$ monobasic potassium phosphate, $137 \mathrm{mM}$ sodium chloride and $2.7 \mathrm{mM}$ potassium chloride at $\mathrm{pH} \mathrm{7.1.}$ Betaferon ${ }^{\circledR}$ (Schering, Berlin, Germany) was obtained from local hospitals and contained $0.25 \mathrm{mg} / \mathrm{ml}$ rhIFN $\beta$ - $1 \mathrm{~b}$ with human serum albumin (HSA), mannitol and sodium chloride after reconstitution of the lyophilized powder according to the manufacturer's instructions.

\section{Characterization of rhIFN $\beta$ - I a Structural Variants}

\section{Visual Inspection}

Samples were inspected visually at the lab bench against a black background and compared with water as a control.

\section{UV Spectroscopy}

UV spectra $(\lambda=190-1,100 \mathrm{~nm})$ of the samples were recorded at $25^{\circ} \mathrm{C}$ on an Agilent 8453 UV/VIS spectrophotometer in quartz cuvettes with a path length of $1 \mathrm{~cm}$. Samples were diluted with the corresponding buffer to a concentration of $100 \mu \mathrm{g} / \mathrm{ml} \mathrm{rhIFN} \beta$ - $1 \mathrm{a}$ and measured in the presence or absence of $0.01 \%(\mathrm{w} / \mathrm{v})$ sodium dodecyl sulfate (SDS). The corresponding sample buffer was used as a blank.

\section{Dynamic Light Scattering (DLS)}

Samples were analyzed with dynamic light scattering (DLS) to obtain an average diameter of the particles (Z-ave) and their polydispersity index (PDI). A Malvern Zetasizer Nano ZS apparatus equipped with a red laser $(\lambda=633 \mathrm{~nm})$, a detector at $173^{\circ}$ and Dispersion Technology Software version 4.20 was used. Samples were diluted with the corresponding buffer to a concentration of $100 \mu \mathrm{g} / \mathrm{ml}$ rhIFN $\beta$ - $1 \mathrm{a}$ and measured in the presence or absence of $0.01 \%(\mathrm{w} / \mathrm{v})$ SDS.

\section{Flow Microscopy}

Particulate matter in $50 \mu \mathrm{g} / \mathrm{ml}$ rhIFN $\beta$ - 1 a samples and the corresponding buffers was measured with a Micro-Flow Imaging instrument type DPA4100 (Brightwell Technologies, Inc., Canada). A high magnification setting allowed the detection of particles in the range of 0.75 to $70 \mu \mathrm{m}$ with an analysis field depth of $100 \mu \mathrm{m}$. Prior to each run, MilliQ water filtered through a $0.22 \mu \mathrm{m}$ filter was flushed through the system to provide a clean background and to optimize illumination. To equilibrate the system, $0.2 \mathrm{ml}$ of sample was dispensed before analysis. Samples were drawn from a $1 \mathrm{ml}$ pipette tip at a flow rate of $100 \mu \mathrm{L} / \mathrm{min}$ using a peristaltic pump and analyzed for 5 minutes. Particle size was measured as the equivalent circular diameter (ECD) representing the diameter of a circle occupying the same projection area as the particle. Aspect ratios (the ratio of the longest dimension to the perpendicular dimension at the midpoint) were derived from 200 images stored during one run.

\section{Fluorescence Spectroscopy}

Fluorescence emission spectra of $50 \mu \mathrm{g} / \mathrm{ml}$ samples were measured at $25^{\circ} \mathrm{C}$ from 310 to $410 \mathrm{~nm}$ with $1 \mathrm{~nm}$ steps in quartz cuvettes with a path length of $1 \mathrm{~cm}$ while stirring. An Edinburgh Instruments Steady State FS 920 fluorimeter was used. Samples were excited at $295 \mathrm{~nm}$, and slits were set at $3 \mathrm{~nm}$. Dwell time per data point was $0.5 \mathrm{~s}$, and the sum of three scans was taken. The corresponding buffer spectra were subtracted. Emission maxima were determined with the FS 900 fluorescence spectrometer software.

\section{High-Performance Size-Exclusion Chromatography (HP-SEC)}

Samples $(100 \mu \mathrm{g} / \mathrm{ml})$ were analyzed with a TSKgel Super SW2000 column and Super SW guard column (Sigma Aldrich), and chromatograms were recorded with a Shimadzu SPD-6AV UV detector. A Waters 515 HPLC pump and 717 Plus autosampler were operated at a flow rate of $0.35 \mathrm{ml} / \mathrm{min}$. The mobile phase consisted of $100 \mathrm{mM}$ sodium phosphate buffer, $200 \mathrm{mM}$ sodium chloride, 0.05\% (w/v) sodium azide and $0.1 \%(\mathrm{w} / \mathrm{v}) \mathrm{SDS}$ at a $\mathrm{pH}$ of 7.2 and was filtered through a $0.2 \mu \mathrm{m}$ filter prior to use.

\section{Sodium Dodecyl Sulfate Polyacrylamide Gel Electrophoresis (SDS-PAGE)}

Pre-cast gels (Ready Gels, Tris-HCl, linear gradient 4 $20 \%$, Biorad, Veenendaal, the Netherlands) were run under non-reducing and reducing (sample buffer containing $5 \%(\mathrm{v} / \mathrm{v}) \beta$-mercaptoethanol) conditions at $200 \mathrm{~V}$ at room temperature. Samples analyzed under reducing conditions were heated at $99^{\circ} \mathrm{C}$ for five minutes before applying to the gel. A volume of $10 \mu \mathrm{l}$ of undiluted sample with $10 \mu \mathrm{l}$ of sample buffer was applied to each well. Sodium dodecyl sulfate polyacrylamide gel electrophoresis (SDS-PAGE) was performed with a Biorad Mini-Protean 3 module. The electrophoresis buffer was $25 \mathrm{mM}$ tris (hydroxymethyl) aminomethane, $192 \mathrm{mM}$ glycine and $0.1 \%$ (w/v) SDS. Prestained broad range molecular weight markers (Biorad) were included for molecular weight determination, and a Silver Stain Plus kit (Biorad) was used to visualize the 
protein bands. The gels were scanned with a Biorad GS800 densitometer and Quantity One software.

\section{Western Blotting}

SDS-PAGE gels were blotted onto a nitrocellulose sheet (VWR International, Amsterdam, the Netherlands) with a Biorad Mini Trans-Blot electrophoretic transfer cell and a transfer buffer containing $10 \mathrm{mM}$ sodium hydrogen carbonate, $3 \mathrm{mM}$ sodium carbonate, $20 \%(\mathrm{v} / \mathrm{v})$ methanol and $0.1 \%$ SDS $(\mathrm{w} / \mathrm{v})$ at $\mathrm{pH}$ 10.0. Blots were blocked overnight at $4{ }^{\circ} \mathrm{C}$ with $8 \%(\mathrm{w} / \mathrm{v})$ non-fat milk powder (ELK, Campina Melkunie, Eindhoven, the Netherlands) in $0.005 \%(\mathrm{w} / \mathrm{v})$ Tween 20 in phosphate-buffered saline (PBS, consisting of $3.6 \mathrm{mM} \mathrm{KH} \mathrm{PO}_{4}, 6.4 \mathrm{mM} \mathrm{Na}_{2} \mathrm{HPO}_{4}$ and $145 \mathrm{mM} \mathrm{NaCl}$ at $\mathrm{pH} 7.2$ ) with constant orbital shaking. After washing with $0.005 \%(\mathrm{w} / \mathrm{v})$ Tween 20 in PBS, the blots were incubated with $0.2 \mu \mathrm{g} / \mathrm{ml}$ polyclonal rabbit anti-rhIFN $\beta$ antibody (Acris Antibodies, Hiddenhausen, Germany) in $0.1 \%(\mathrm{w} / \mathrm{v})$ non-fat milk powder and $0.005 \%$ $(\mathrm{w} / \mathrm{v})$ Tween 20 in PBS for one hour at room temperature with constant orbital shaking. Blots were washed with $0.005 \%(\mathrm{w} / \mathrm{v})$ Tween 20 in PBS. Blots were incubated with peroxidase-labeled goat anti-rabbit immunoglobulin $\mathrm{G}$ (IgG) (Sigma Aldrich), diluted 1000-fold in PBS containing $0.1 \%(\mathrm{w} / \mathrm{v})$ non-fat milk powder and $0.005 \%(\mathrm{w} / \mathrm{v})$ Tween 20 , for one hour at room temperature with constant orbital shaking. Blots were washed with $0.005 \%(\mathrm{w} / \mathrm{v})$ Tween 20 in PBS and incubated in a solution of $0.05 \%(\mathrm{w} / \mathrm{v})$ 4-chloro-1naphtol (Sigma-Aldrich) in $17 \%(\mathrm{v} / \mathrm{v})$ methanol and $0.0125 \%$ (v/v) $\mathrm{H}_{2} \mathrm{O}_{2}$. After color development, the blots were stored overnight in the dark in water to increase the intensity of the bands.

\section{Immunogenicity Study}

\section{Mouse Breeding}

Heterozygous C57Bl/6 transgenic mice immune tolerant for hIFN $\beta$, developed by Hermeling et al. (20), were bred at the Central Laboratory Animal Institute (Utrecht University, the Netherlands). The strain was maintained by crossing the transgenics with wild-type $\mathrm{C} 57 \mathrm{Bl} / 6$ mice obtained from Janvier (Bioservices, Uden, the Netherlands). The genotype of the offspring was determined by PCR showing the presence or absence of the hIFN $\beta$ gene in chromosomal DNA isolated from ear tissue. Transgenic C57Bl/6 mice were crossed with wild-type $\mathrm{FVB} / \mathrm{N}$ mice obtained from Janvier (BioServices), and their $\mathrm{C} 57 \mathrm{Bl} / 6 \times \mathrm{FVB} / \mathrm{N}$ hybrid offspring were genotyped using PCR. Both transgenic $\mathrm{C} 57 \mathrm{Bl} / 6 \times \mathrm{FVB} / \mathrm{N}$ hybrid mice and their non-transgenic (wild-type) littermates, evaluated previously as a mouse model for human interferon beta (17), were used.

\section{Animal Experiment}

The animal experiments were approved by the Institutional Ethical Committee. Food (Hope Farms, Woerden, the Netherlands) and water (acidified) were available ad libitum. Blood was drawn from the cheek pouches (submandibularly) of 32 wild-type and 32 transgenic mice before starting the treatment $(17,20)$. Eight mice per group were injected intraperitoneally (i.p.) with $5 \mu \mathrm{g}$ of bulk, reformulated or stressed rhIFN $\beta$ - $1 \mathrm{a}$, or $5 \mu \mathrm{g}$ of Betaferon ${ }^{\circledR}$-rhIFN $\beta$ - $1 \mathrm{~b}$ on days 0 to 4 , days 7 to 11 and days 14 to 18 . After an injection-free period of 6 weeks, all mice were rechallenged with $5 \mu \mathrm{g}$ of reformulated rhIFN $\beta$-1a i.p. on days 63 and 64 . Blood was collected submandibularly from two out of eight mice per group per time point, just before treatment with $\operatorname{rhIFN} \beta$, on days $4,7,11,14,18,21,28,43,53,56$, $58,60,64,65,66$ and 67 . If administered $\operatorname{rhIFN} \beta$ is not completely cleared from the circulation before blood drawing, remaining rhIFN $\beta$ levels could interfere with the $\mathrm{BAB}$ assay. Therefore, we performed an additional study following rhIFN $\beta$ blood levels in time with ELISA after a single i.p. injection of $5 \mu \mathrm{g}$ of Betaferon ${ }^{\circledR}$-rhIFN $\beta-1 \mathrm{~b}$ or bulk rhIFN $\beta$-1a in wild-type hybrid mice. From this study, we estimated that the half-lives of $\operatorname{rhIFN} \beta-1 \mathrm{~b}$ and $\operatorname{rhIFN} \beta$ 1a in the mice were 2.5 and 4.5 hours, respectively. Since the time interval between the previous dose and the blood sampling on days 4, 11, 18, 64 and 65 was relatively short (i.e. 20 to 24 hours), low levels of rhIFN $\beta$-1a may have remained in the plasma samples of these days. For the other blood sampling days and for rhIFN $\beta$ - 1 b, most likely sufficient time passed after the previous dose to allow for clearance of the protein from the circulation. On day 77 , all mice were sacrificed by bleeding through cardiac punction under isofluran anesthesia. Blood samples were collected in lithium heparin gel tubes and centrifuged for $10 \mathrm{~min}$ at $3,000 \mathrm{~g}$, and the obtained plasma was stored at $-80^{\circ} \mathrm{C}$ until analysis.

\section{Binding Antibody Assay}

Titers of BABs against rhIFN $\beta$ were measured in the plasma by direct ELISA according to the protocol described in detail by Hermeling et al. (20) with minor changes. Plates were coated with bulk rhIFN $\beta$-la and blocked with $4 \%$ milk powder and $0.1 \%$ Tween 20 in PBS at room temperature for two hours. Plasma samples and the secondary antibody (horseradish peroxidase coupled anti-mouse IgG from Invitrogen, Zymed) were diluted in the blocking buffer described above in a ratio of 1:100 and 1:4000, respectively. Color conversion was initiated by adding $100 \mu \mathrm{l}$ of 3,3',5,5'-tetramethylbenzidine (Roche) and stopped by adding $100 \mu \mathrm{l}$ of $0.18 \mathrm{M}$ sulfuric acid. Absorbance values were measured with an immuno plate reader (Novopath, Biorad) at a wavelength of $450 \mathrm{~nm}$. The 
100-fold diluted plasma samples were screened and defined positive if their mean absorbance values were at least three times higher than the $95^{\text {th }}$ percentile value of negative control plasma. The titer of anti-hIFN $\beta$ IgG in positive plasma was determined by plotting the absorbance values of a 2-fold serial dilution against log dilution. The plots were fitted to a sigmoidal dose-response curve using GraphPad Prism version 4.0 for Windows (GraphPad Software, San Diego CA, USA). The reciprocal of the dilution of the EC50 value was defined as the BAB titer.

\section{Neutralizing Antibody Assay}

NAB levels in the plasma samples of day 77 were assessed in a bioassay based on inhibition of induction of myxovirus resistance protein A (MxA) gene expression in an A549 cell line as previously described (21). The type of $\operatorname{rhIFN} \beta(-1 \mathrm{a}$ or $-1 \mathrm{~b}$ ) used in the assay was the same as the type used for injecting the animal. Both $\mathrm{MxA}$ and a control household gene-derived mRNA (eukaryotic 18S rRNA) were detected with a real-time RT-PCR multiplex assay. Neutralizing activity was expressed in ten-fold reduction units per $\mathrm{ml}$ (TRU/ml). Plasma samples with a neutralizing activity below $130 \mathrm{TRU} / \mathrm{ml}$ were considered negative. Positive samples showed neutralizing activities ranging from 1143 $\mathrm{TRU} / \mathrm{ml}$ to more than $5120 \mathrm{TRU} / \mathrm{ml}$.

\section{RESULTS AND DISCUSSION}

\section{Characterization of rhIFN $\beta$ - I a Structural Variants}

\section{Visual Inspection}

The three rhIFN $\beta$ - la solutions were colorless and transparent, and visual inspection did no reveal visible aggregation or precipitation.

\section{UV Spectroscopy}

All UV spectra showed broad absorbance peaks around the wavelength of $280 \mathrm{~nm}$, indicating tryptophan, tyrosine or phenylalanine residues or disulfide bonds in the rhIFN $\beta$-la samples (Fig. 1A) (22,23). Protein aggregates cause scattering of light that can be observed as an increase in optical density (OD) (23). The wavelength-dependent light scattering intensity is influenced by several factors, such as aggregate size, shape and amount. As a measure for aggregation, the OD at $350 \mathrm{~nm}$ (OD350) and the ratio between the OD at $280 \mathrm{~nm}$ and $260 \mathrm{~nm}$ (OD280/OD260) were used (Table I). As compared with reformulated $\operatorname{rhIFN} \beta$-la $(\mathrm{OD} 350=0.02$; OD280/OD260 = 1.67), bulk and stressed $\operatorname{rhIFN} \beta-1 \mathrm{a}$ showed a high OD350 (0.11 and 0.08, respectively) and a low OD280/OD260 (1.12 and 1.01), indicating the presence of aggregates (Table I). Light scattering at high wavelengths was most pronounced in bulk rhIFN $\beta$-la, which suggests the presence of large aggregates. Stressed rhIFN $\beta$-la showed the lowest OD280/OD260, most likely caused by absorption flattening due to extensive aggregation of the sample (23).

Aggregates of rhIFN $\beta$ formed by non-covalent protein bonds can be disassembled by SDS (24). Adding $0.01 \%$ SDS changed the UV spectrum of bulk rhIFN $\beta$-la drastically (Fig. 1A). Its OD350 and A280/A260 became similar to those of reformulated rhIFN $\beta$-1a with SDS (Table I), indicating non-covalently bound aggregates. In contrast, the UV spectrum of stressed rhIFN $\beta$-1a changed only slightly after adding SDS, suggesting the presence of a considerable amount of covalent aggregates. The initial OD350 and OD280/OD260 values, together with the marginal decrease in OD350 and increase in OD280/ OD260 following the addition of SDS suggest a low level of non-covalent aggregates in reformulated $\operatorname{rhIFN} \beta$-1a.

\section{Dynamic Light Scattering (DLS)}

According to studies on rhIFN $\beta$-la crystals performed by Karpusas et al., the protein has a cylindrical shape of roughly $2 \times 3 \times 4 \mathrm{~nm}(25)$. Bulk rhIFN $\beta$-la showed a large $\mathrm{Z}$-ave $(2,300 \mathrm{~nm})$ and a large PDI (0.9), indicating that the sample contained aggregates heterogeneous in size (Table I). As the light scattering intensity is proportional to the sixth power of the particle radius, the size average of the protein sample is overestimated $(26,27)$. The strong light scattering of the aggregates inhibits the detection of the rhIFN $\beta$-la monomer, which may represent a much larger fraction by weight than the aggregated material (27). As the size distributions varied considerably between repeated measurements, only $\mathrm{Z}$-ave and PDI results are presented. The Z-ave and PDI of reformulated rhIFN $\beta$-1a could not be determined due to the small size of the monomer, the low protein concentration and lightscattering components in the formulation buffer (i.e. arginine and Tween 20). Stressed rhIFN $\beta$-1a also contained aggregates, which were smaller (95 nm) and more homogeneous $(\mathrm{PDI}=0.3)$ in size than the aggregates in bulk rhIFN $\beta$-1a. In concordance with our observations from UV spectroscopy, the addition of $0.01 \%$ SDS resulted in a large decrease in Z-ave (from 2,300 to $27 \mathrm{~nm}$ ) and PDI (from 0.9 to 0.3 ) of bulk rhIFN $\beta$-1a, reflecting the dissociation of noncovalent protein complexes, whereas the mainly covalently bound aggregates in stressed rhIFN $\beta$-la stayed intact.

\section{Flow Microscopy}

Flow microscopy enables the detection of protein particulates larger than $0.75 \mu \mathrm{m}$ that are difficult to study with 
(A)

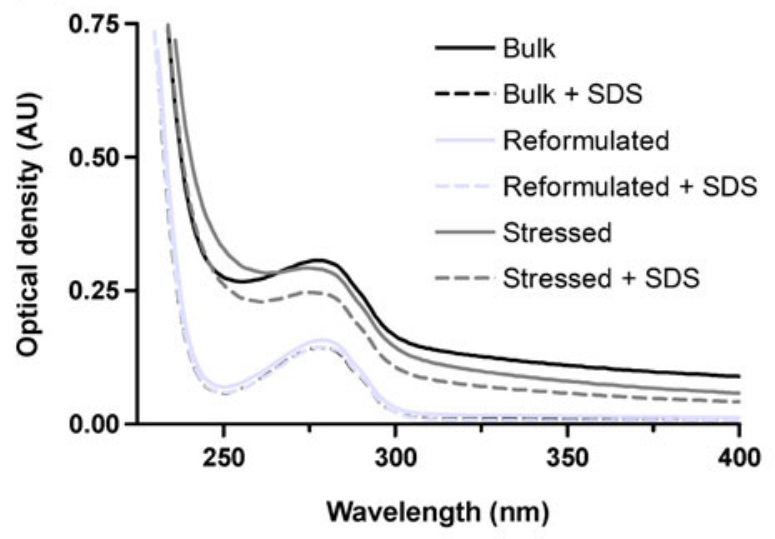

(C)

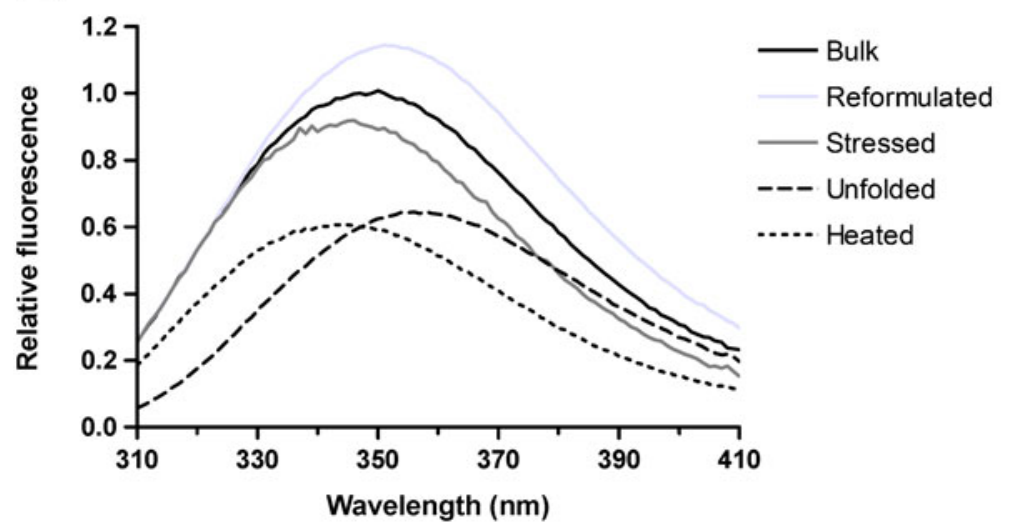

(B)

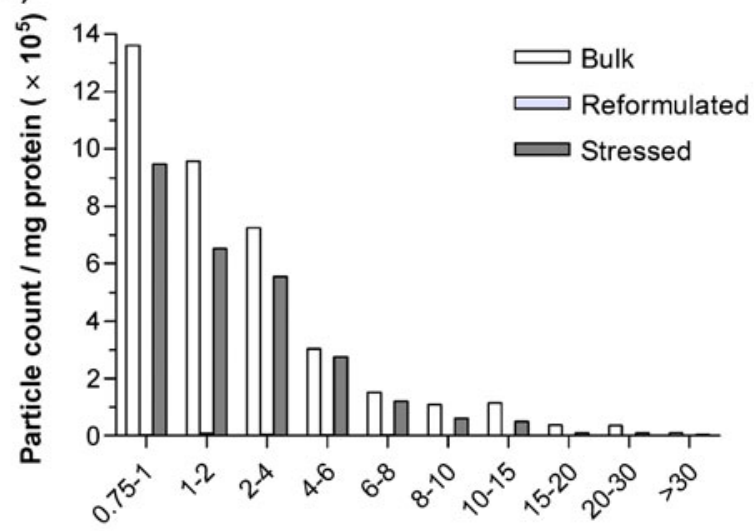

Size range $(\mu \mathrm{m})$

(D)

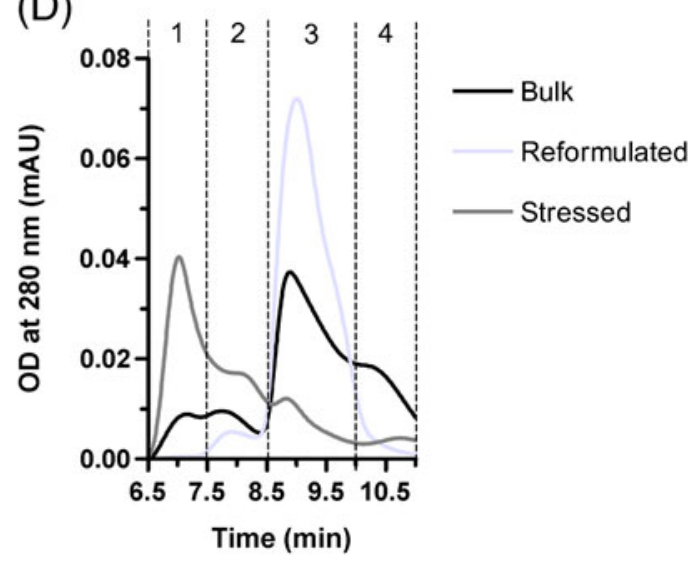

Fig. I Graphs showing (A) UV spectra in the absence and presence of $0.01 \%(\mathrm{~W} / \mathrm{V}) \mathrm{SDS}$, (B) particle distributions in specified size ranges based on flow microscopy analysis (with hardly any particles detected in reformulated rhIFN $\beta$ - Ia), (C) fluorescence emission spectra (with rhIFN $\beta$ - Ia unfolded in 6 M guanidine hydrochloride and rhIFN $\beta$ - I a heated at $90^{\circ} \mathrm{C}$ for $10 \mathrm{~min}$, for comparison), and (D) size-exclusion chromatograms, of bulk, reformulated and stressed rhIFNß-Ia. The HP-SEC peaks (D) are numbered from I to 4 (see text for details), with the vertical dashed lines showing the range of each peak.

more conventional techniques such as UV, DLS, HP-SEG and SDS-PAGE. Reformulated rhIFN $\beta$-la showed a low particle count that was slightly higher than the particle count of the buffer control, which was $0.32 \times 10^{3}$ particles $/ \mathrm{ml}$, whereas the particle counts of bulk and stressed rhIFN $\beta$-la were two orders of magnitude higher (Fig. 1B and Table I). Particle contents of bulk and stressed rhIFN $\beta$ - la were in the same range, and both samples had similar size distributions, mean sizes and mean aspect ratios. Thus, the aggregates larger than $0.75 \mu \mathrm{m}$ in bulk and stressed $\operatorname{rhIFN} \beta$-la were comparable in size, quantity and shape, while such aggregates were practically absent in reformulated $\operatorname{rhIFN} \beta$-1a.

\section{Fluorescence Spectroscopy}

At a wavelength of $295 \mathrm{~nm}$ the tryptophans of $\operatorname{rhIFN} \beta$-1a were excited, and a typical emission maximum around $350 \mathrm{~nm}$ was observed (Fig. 1G). The wavelength of the fluorescence peak and its intensity provide information on the environment of the tryptophan at position $22(\operatorname{Trp} 22)$, which is close to the receptor binding site and relatively exposed to the solvent $(28,29)$, and of the tryptophans at positions 79 and 143, which are both inside the hydrophobic core of the protein that is stabilized through several hydrogen bonds and one disulfide bridge $(25,28,29)$. The maximum fluorescence intensity of bulk rhIFN $\beta$-1a (at $349 \mathrm{~nm}$ ) was arbitrarily set at 1, and the fluorescence intensities of the other samples were calculated relative to this value (Table I). The fluorescence emission peak of reformulated rhIFN $\beta$ - 1 a showed a $3 \mathrm{~nm}$ red-shift and $14 \%$ increase in intensity in comparison with bulk $\operatorname{rhIFN} \beta-1 \mathrm{a}$, which may be attributed to the lower degree of aggregation and more exposed tryptophans (30,31). For comparison, the spectrum of rhIFN $\beta$-la unfolded in $6 \mathrm{M}$ guanidine hydrochloride showed a considerably larger red-shift of $8 \mathrm{~nm}$ (Fig. 1C). Stressed rhIFN $\beta$-1a showed a $4 \mathrm{~nm}$ blueshift and an $8 \%$ intensity decrease in the fluorescence 
Table I Overview of the Physicochemical Characteristics of Bulk, Reformulated and Stressed rhIFN $\beta$ - Ia

\begin{tabular}{|c|c|c|c|c|}
\hline Method & Parameter & Bulk & Reformulated & Stressec \\
\hline \multirow[t]{4}{*}{ UV } & OD280/OD260 & 1.12 & 1.67 & 1.01 \\
\hline & OD280/OD260 with SDS ${ }^{a}$ & 1.74 & 1.76 & 1.06 \\
\hline & OD350 nm & 0.11 & 0.02 & 0.08 \\
\hline & OD350 nm with SDS ${ }^{a}$ & 0.01 & 0.01 & 0.06 \\
\hline \multirow[t]{4}{*}{ DLS } & Z-ave (nm) & 2300 & $N D^{b}$ & 95 \\
\hline & Z-ave with $\mathrm{SDS}^{a}(\mathrm{~nm})$ & 27 & $N D^{b}$ & 120 \\
\hline & PDI & 0.9 & $N D^{b}$ & 0.3 \\
\hline & PDI with SDS ${ }^{a}$ & 0.3 & $N D^{b}$ & 0.3 \\
\hline \multirow[t]{3}{*}{ Flow microscopy } & Mean size $\left(E C D^{c} ; \mu \mathrm{m}\right)$ & 3.0 & 3.3 & 2.7 \\
\hline & Total particle count $\left(\times 10^{3} / \mathrm{ml}\right)$ & 190 & 0.82 & 134 \\
\hline & Mean aspect ratio $(0-1)$ & 0.67 & 0.70 & 0.68 \\
\hline \multirow[t]{2}{*}{ Fluorescence } & Emission maximum (nm) & 349 & 352 & 345 \\
\hline & Relative peak intensity & 1.00 & 1.14 & 0.92 \\
\hline \multirow[t]{5}{*}{ HP-SEC ${ }^{d}$} & Fraction peak I (\%) & 8 & 0 & 31 \\
\hline & Fraction peak 2 (\%) & 10 & 6 & 21 \\
\hline & Fraction peak 3 (\%) & 50 & 83 & 14 \\
\hline & Fraction peak 4 (\%) & 19 & 4 & 5 \\
\hline & Unrecovered fraction (\%) & 13 & 7 & 29 \\
\hline
\end{tabular}

emission maximum, indicating a higher degree of aggregation. The same effect was observed previously by Fan et al. during heat-induced aggregation of $\operatorname{rhIFN} \beta$-1a (32). Nevertheless, Trp22 in stressed rhIFN $\beta$-la seems to be more accessible than a $\operatorname{rhIFN} \beta$-la sample that was denatured by heating for $10 \mathrm{~min}$ beyond its transition temperature (Fig. 1G). Contrary to the heated sample, stressed rhIFN $\beta$-1a probably retained most of its native tertiary structure.

\section{High-Performance Size-Exclusion Chromatography (HP-SEC)}

Runkel et al. described the use of a TSKgel SW2000 HPSEC column with a mobile phase of $100 \mathrm{mM}$ sodium phosphate and $200 \mathrm{mM} \mathrm{NaCl}$ at $\mathrm{pH} 7.2$ to analyze rhIFN $\beta$-1a and rhIFN $\beta$-1b products with large amounts of human serum albumin (HSA) (7). HSA is commonly used in formulations to prevent adsorption of hydrophobic protein products $(7,33,34)$. The absence of HSA in our rhIFN $\beta$-1a formulations may explain the low protein recovery of our samples in this HP-SEC procedure, i.e. $42 \%$ for bulk, $81 \%$ for reformulated and $61 \%$ for stressed rhIFN $\beta$-1a (data not shown). Therefore, to inhibit adsorption of the protein to the solid phase and increase resolution, we added $0.1 \% \mathrm{SDS}$ to our mobile phase $(35,36)$. This resulted in improved recoveries of $87 \%$ for bulk, 93\% for reformulated and $71 \%$ for stressed $\operatorname{rhIFN} \beta$ 1a. The SDS in our elution buffer disrupts non-covalently bound protein complexes, and it hinders molecular weight calibration with standard proteins, so we numbered the different peaks as Peak 1-4 in order of elution (Fig. 1D).
Most bulk rhIFN $\beta$-1a eluted in Peak $3(50 \%)$, which is most likely the rhIFN $\beta$-1a monomer (Table I). Another significant amount eluted in Peak 4 (19\%), probably consisting of monomeric proteins of which the hydrophobic cores are slightly exposed, causing interactions with the column material. Peak $1(8 \%)$ of the bulk sample eluted in the void volume of the column corresponding to soluble protein aggregates with a molecular weight higher than $150 \mathrm{kDa}$. The protein fraction in Peak $2(10 \%)$ is probably a dimer, which has been reported before $(7,25)$. The non-recovered fraction comprised $13 \%$ of the bulk sample and probably contained covalent aggregates too large to enter the column or unfolded protein irreversibly attached to the column material. The reformulated sample contained 83\% monomers, and its total sample recovery was high (93\%). The majority of the stressed sample eluted in the higher molecular weight regions $(31 \%$ in Peak 1 and $21 \%$ in Peak 2) and contained a non-recovered fraction of $29 \%$.

\section{Sodium Dodecyl Sulfate Polyacrylamide Gel Electrophoresis (SDS-PAGE)}

We applied denaturing polyacrylamide gel electrophoresis to assess the relative molecular masses of $\operatorname{rhIFN} \beta-1 \mathrm{a}$ monomer, fragments, and covalent aggregates (37). Under non-reducing conditions, bulk rhIFN $\beta$-1a contained monomer, dimer, trimer and larger aggregates (Fig. 2A, lane B). The additional band at approximately $19.5 \mathrm{kDa}$ most likely corresponds with a deglycosylated, monomeric form of rhIFN $\beta$-1a $(7,38)$. Under reducing conditions, the monomer and dimer showed a slight increase in apparent mass, 
(A)

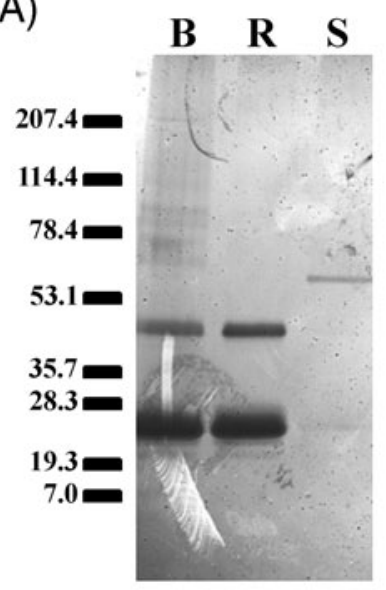

(C)

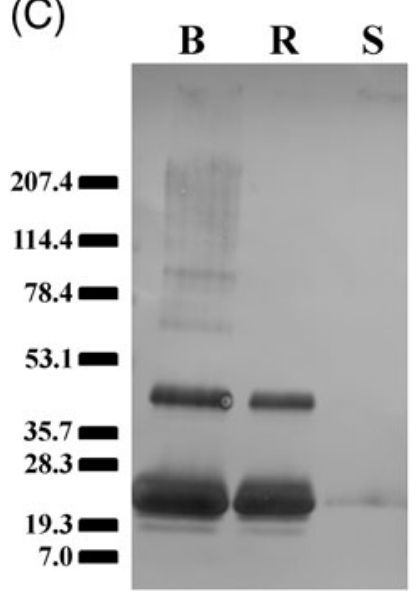

(B)

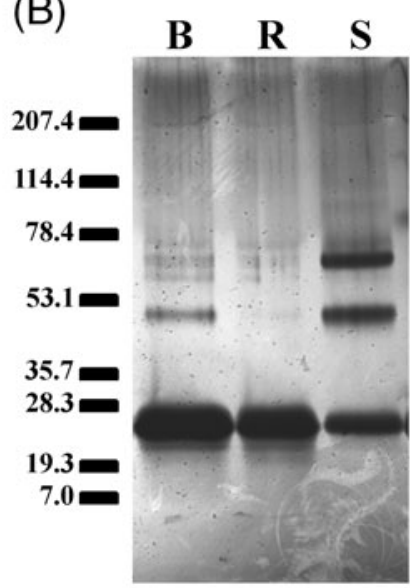

(D)
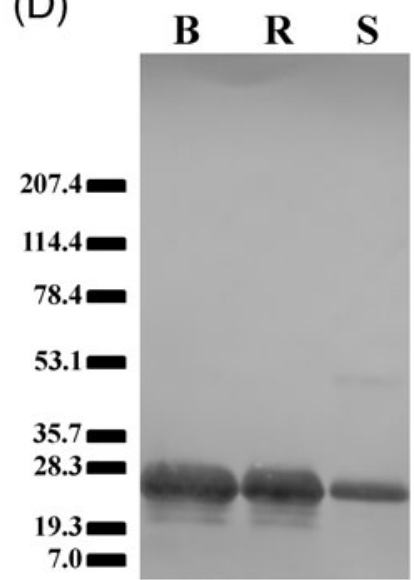

Fig. 2 SDS-PAGE gels under (A) non-reducing and (B) reducing conditions and the corresponding Western blots of the gels under (C) non-reducing and (D) reducing conditions of the three structural variants of rhIFNß-Ia. Numbers on the left represent band positions (in $\mathrm{kDa}$ ) of the molecular weight markers. Lane $B=$ bulk rhIFN $\beta-I \mathrm{a} ; R=$ reformulated rhIFN $\beta-1 \mathrm{a}$; and $\mathrm{S}=$ stressed rhIFN $\beta-\mathrm{la}$.

which is probably due to the breaking of the intramolecular disulfide bridge of rhIFN $\beta$-la (Fig. 2B, lane B). The decreased intensity of the dimer band observed under these conditions indicates that at least some of the dimers in bulk rhIFN $\beta$-la were formed through disulfide bonds. The covalent trimers and larger aggregates were non-disulfide mediated.

For reformulated rhIFN $\beta$-1a, non-reducing SDS-PAGE showed monomers and dimers without any trimers or larger aggregates, similar to what was seen by HP-SEC (cf. Fig. 1D and Fig. 2A, lane R). Reducing SDS-PAGE showed that the dimers in reformulated $\operatorname{rhIFN} \beta$-1a were mainly formed through disulfide bridges (Fig. 2B, lane R).

Under non-reducing conditions, stressed rhIFN $\beta$-la was hardly able to enter the gel due to its high percentage of covalent aggregates (Fig. 2A, lane S). Reducing SDS-PAGE showed that the aggregates contained reducible bonds, as is

clear from the monomers, dimers and trimers observed (Fig. 2B, lane S). Non-reducing SDS-PAGE (Fig. 2A) confirms the proposed nature of the various peaks observed during HP-SEC (Fig. 1D).

\section{Western Blotting}

The polyclonal anti-rhIFN $\beta$-1a antibodies used for Western blotting reacted with the monomeric bands in all three rhIFN $\beta$-1 a products under both non-reducing and reducing conditions, including the barely visible monomeric band of stressed rhIFN $\beta$-la under non-reducing conditions (Figs. 2C and 2D). Also, dimers, trimers and larger aggregates in bulk rhIFN $\beta$ - 1 a and dimers in reformulated rhIFN $\beta$-la were recognized by the antibodies under nonreducing conditions (Fig. 2G). In contrast, none of the nonreducible covalent protein complexes in bulk, reformulated or stressed rhIFN $\beta$-la were recognized by the antibodies (Fig. 2D), suggesting the destruction of specific epitopes upon formation of covalent links between monomers.

\section{Summary}

Bulk rhIFN $\beta$-la was shown to contain monomeric protein and a low amount of heterodisperse $\operatorname{rhIFN} \beta$-la aggregates with sizes ranging from dimers to aggregates of several micrometers. The aggregates were mainly formed through non-covalent bonds and disulfide linkages, and contained intact epitopes. In addition, some covalent, non-reducible aggregates were present that were not recognized by the polyclonal antibody used for Western blotting.

Reformulated rhIFN $\beta$-la showed low aggregate levels, mainly dimers containing intact epitopes.

Stressed rhIFN $\beta$-la contained a high percentage of rather homogeneously sized covalent aggregates with a size of approximately $100 \mathrm{~nm}$. Importantly, the covalent nonreducible aggregates did not contain detectable native epitopes.

\section{Immunogenicity}

In order to test the immunogenicity of the three rhIFN $\beta$ - 1 a samples, the same schedule of injections was used as before $(8,10,17,20)$. Fig. 3 shows the levels of IgG antibodies in wild-type and transgenic mice injected with the three different products. Please note that the presented BAB titers on days 4, 11 and 18 in the mice treated with bulk, reformulated and stressed rhIFN $\beta$-la might be underestimated due to low levels of rhIFN $\beta$-1a in these samples. In general, the wild-type mice started to produce $\mathrm{BABs}$ between day 4 and day 11 and developed high $\operatorname{IgG}$ titers against all products. These high BAB levels persisted in the wild-types. With the exception of two mice that did not 
(A)

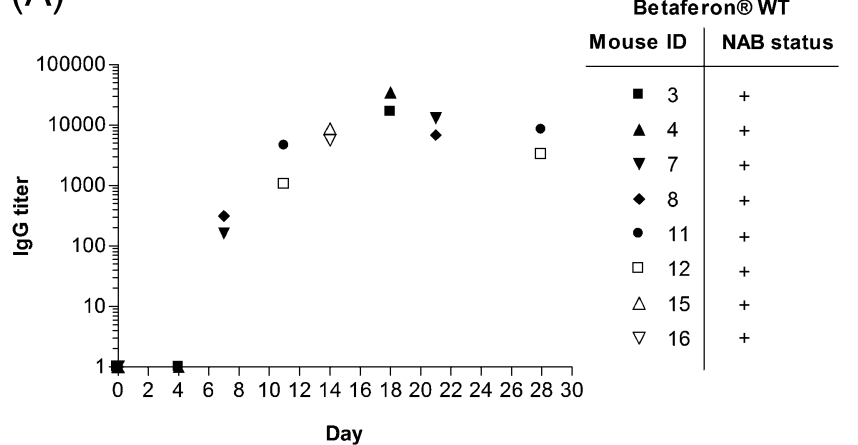

(C)

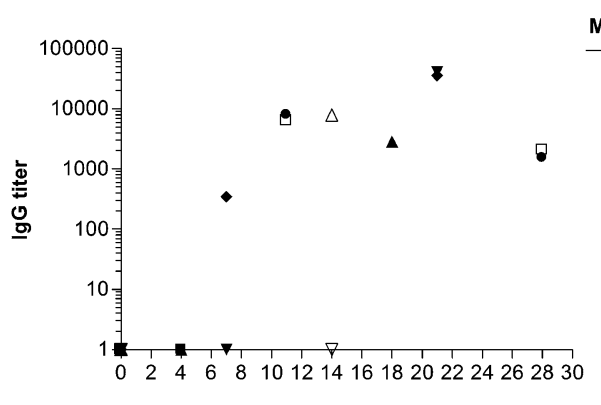

Day

(E)

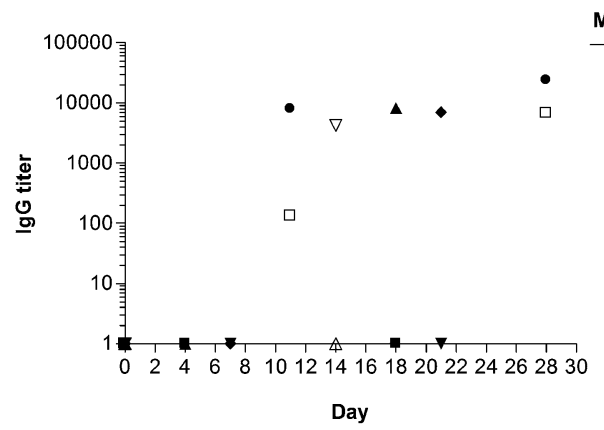

(G)

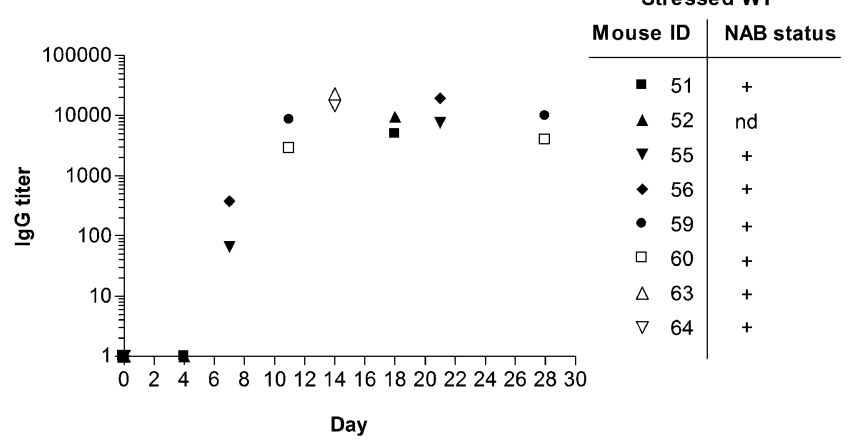
Mouse ID NAB status

\begin{tabular}{ll|c} 
- & 35 & - \\
V & 36 & + \\
- & 49 & - \\
- & 43 & + \\
$\square$ & 44 & + \\
$\triangle$ & 47 & nd \\
$\nabla$ & 48 & +
\end{tabular}

(B)

Betaferon ${ }^{\circledR}$ TG

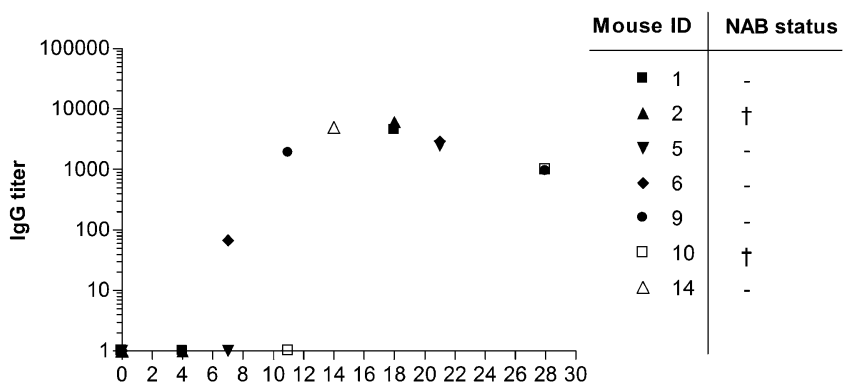

Day

(D)

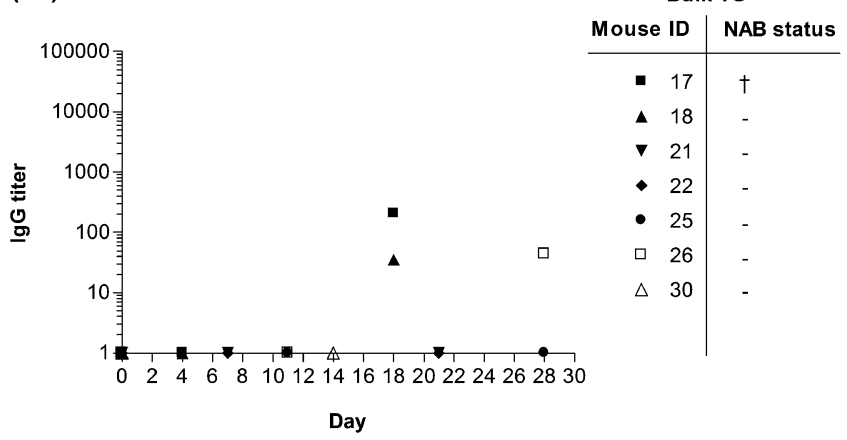

(F)

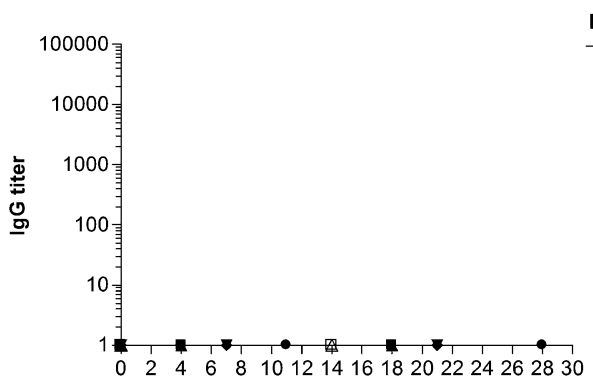

Reformulated TG

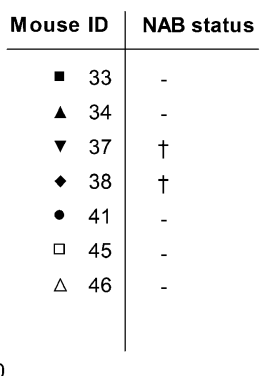

Day

(H)

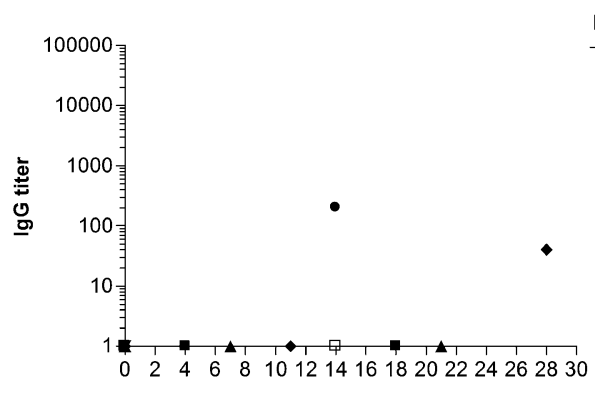

Day

Fig. 3 Immunogenicity of $(A, B)$ Betaferon ${ },(C, D)$ bulk rhIFN $\beta-I a,(E, F)$ reformulated rhIFN $\beta$ - Ia, and $(G, H)$ stressed rhlFN $\beta$ - Ia. Titers of total lgG against rhIFN $\beta$ in plasma of (A, C, E and $G$ ) wild-type $(W T)$ and $(B, D, F$ and $H$ ) transgenic (TG) mice injected daily, from Monday to Friday, i.p. with Betaferon ${ }^{\circledR}$ or one of the rhIFN $\beta$ - I a preparations for three weeks starting at day 0 . Non-responders were given an arbitrary titer of $I$. The legend shows the NAB status of the individual mice in the treatment group at day 77, with $(+)$ positive for NABs, $(-)$ negative for NABs, $(+)$ died before day 77 , and $(n d)$ not determined. Seven out of 64 mice died during the study due to handling or other reasons, such as liver or heart problems. There were no signs of anaphylactic responses. 
respond to reformulated $\operatorname{rhIFN} \beta$-la, the wild-type mice also developed NABs against the products (Fig. 3A, C, E, and G). The formation of both BABs and NABs in these animals indicated that the native protein conformation in all preparations was at least partly intact.

Transgenic mice, on the other hand, did not develop NABs against any of the products (Fig. 3B, D, F, H). Betaferon ${ }^{\circledR}$, used as a positive control, broke the immune tolerance of the transgenics but did not induce NAB formation (Fig. 3B), in keeping with previous observations $(17,20)$. Three out of seven transgenic mice treated with bulk rhIFN $\beta$-1a showed low IgG titers at a single time point (Fig. 3D), indicating a low immunogenicity of this material in transgenic mice. Reformulated rhIFN $\beta$-la did not break the immune tolerance of any of the transgenic mice (Fig. 3F). From the low, transient IgG titers in only two out of six transgenic mice treated with stressed $\operatorname{rhIFN} \beta-1 \mathrm{a}$, it followed that the stressed product was hardly immunogenic (Fig. 3H).

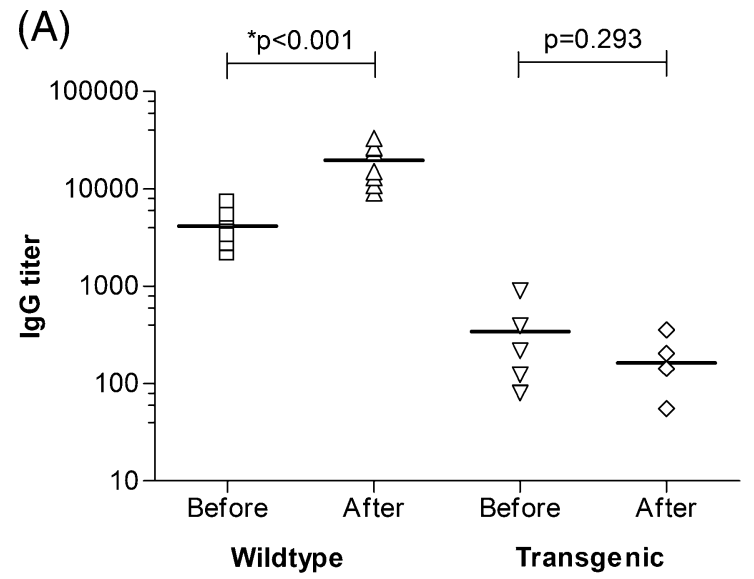

(C)

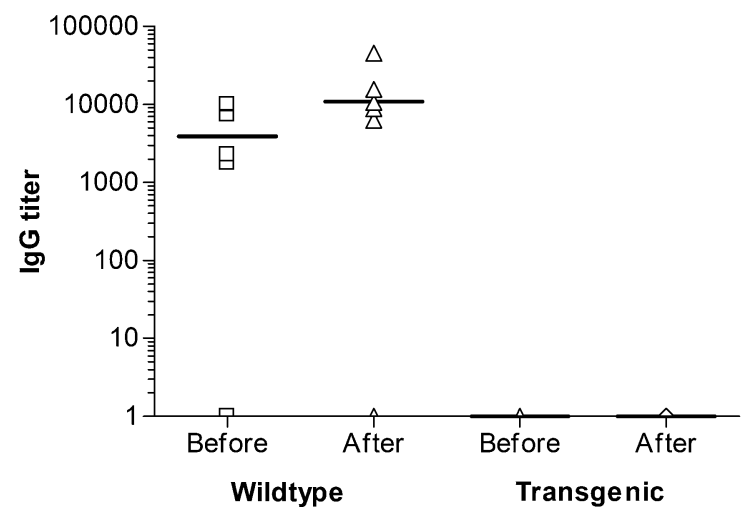

Some of the transgenic mice showed a wild-type-like immune response, including NABs and high, persistent IgG titers. Although they possessed the transgene (as detected by PCR), they were not expressing hIFN $\beta$ and lacked immune tolerance, as was discussed in our previous publication describing the hybrid transgenic mouse model (17). The hIFN $\beta$ gene of the transgenic mice is situated behind the promoter of murine IFN $\beta$, and its expression can be stimulated upon injection with polyICLC (20). Without polyICLC injection, hIFN $\beta$ expression levels are not measurably different between wild-type and transgenic mice. The mice need to be naïve for immunogenicity testing and therefore cannot be treated with polyICLC beforehand. Instead, we analyzed the results of individual transgenic mice for the presence of both (i) NABs and (ii) IgG titers exceeding 2,000 up to 8 weeks after the first injection. Based on these two selection criteria, the data of five transgenic mice (with ID numbers 13, 29, 42, 50 and 54) that showed a wild-type-like immune response were left
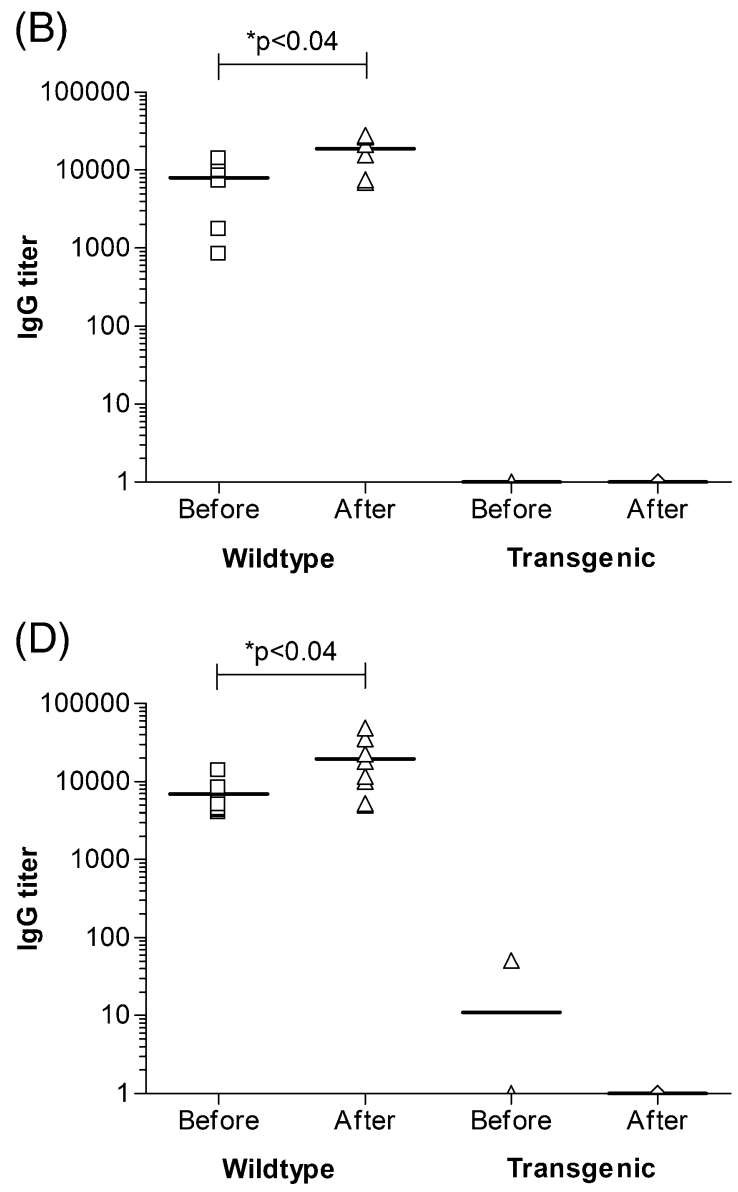

Fig. 4 Titers of total $\lg G$ against rhIFN $\beta$ in individual mice on day 53, 56, 58 or 60 before the rechallenge (before) and at day 77 after the rechallenge (after) with reformulated rhIFN $\beta$ - Ia in plasma of wild-type (left) and transgenic (right) mice treated with (A) Betaferon $B$, (B) bulk rhIFN $\beta$ - Ia, (C) reformulated rhIFN $\beta-I a$, and (D) stressed rhIFN $\beta-I a$. Mean titers and titers of individual mice are shown, and non-responders were given an arbitrary titer of I. Statistical analyses (unpaired $t$ test, two-tailed) were performed between groups with $100 \%$ responders on log ${ }_{10}$ converted titers. Asterisks indicate that titers are significantly $(p<0.04)$ higher after the rechallenge than before. 
out, as they would distort our conclusions on the ability of the rhIFN $\beta$-la samples to break immune tolerance. Generally, we observe about $10-20 \%$ hybrid hIFN $\beta$ transgenic mice in our studies exhibiting a wild-type-like immune response independent of the type of treatment. In the current study, we identified five outliers out of 32 transgenic mice $(16 \%)$, i.e. $1 / 8$ rhIFN $\beta-1 \mathrm{~b}, 1 / 8$ bulk rhIFN $\beta-1 \mathrm{a}, 1 / 8$ reformulated rhIFN $\beta$ - $1 \mathrm{a}$ and $2 / 8$ stressed $\operatorname{rhIFN} \beta$-la treated transgenic mice. All outliers showed high persistent levels of BABs, and they produced NABs while the other transgenics did not. The equal distribution of the outliers among the treatment groups clearly indicates that the effect is not product-related.

\section{Immunological Memory}

Before the rechallenge with reformulated rhIFN $\beta$-1a at day 63, wild-type mice showed high IgG titers (Fig. 4). After the rechallenge, the wild-type mice showed IgG titers at day 70 that were higher than before the rechallenge, independent of the treatment group (Fig. 4A-D). Such an enhanced secondary immune response is characteristic for a T-celldependent immune response typically observed after vaccination with foreign protein $(14,39)$. Transgenic mice treated with Betaferon ${ }^{\circledR}$, however, showed a slight decrease in $\mathrm{BAB}$ level after the rechallenge with reformulated rhIFN $\beta-1 a$, indicating that they had not developed immunological memory for $\operatorname{rhIFN} \beta$ (Fig. 4A). Also bulk, reformulated and stressed rhIFN $\beta$-la-treated transgenics did not show any BABs after the rechallenge, indicating the absence of memory (Fig. 4B-D).

These results comply with the lack of antibody response observed in patients who, after a wash-out period, switched to Avonex®-rhIFN $\beta$-1a treatment after having developed high levels of anti-rhIFN $\beta-1 \mathrm{~b}$ antibodies following Betaferon ${ }^{\circledR}$ treatment (15). Despite the cross-reactivity of antirhIFN $\beta$ antibodies, levels of pre-occurring BABs or NABs in patients did not increase after switching the treatment from Betaferon ${ }^{\circledR}$ to Avonex ${ }^{\circledR}(15,40)$, from rhIFN $\beta$ - 1 a to high-dose intravenous rhIFN $\beta-1 \mathrm{~b}$ (41), and from 1.6 to 8 million international units of rhIFN $\beta$-1b (42), without a wash-out period. Especially patients with low titers may even reconvert to antibody negativity while treatment continues, independent of the type of $\operatorname{rhIFN} \beta$ that is administered (40,43-46). The observed lack of immunological memory in immune-tolerant mice as well as in RR-MS patients may be characteristic for the breakage of B-cell tolerance for recombinant human therapeutic proteins.

\section{FINAL REMARKS AND CONCLUSIONS}

Bulk rhIFN $\beta$-1a, which contained mainly non-covalently bound aggregates, induced a transient immune response in approximately $40 \%$ of the transgenic mice. Filtration of the bulk product reduced the aggregation level, and reformulation in another buffer prevented the formation of new aggregates, thereby completely abolishing its potency to break immune tolerance. Despite the high percentage of aggregates in stressed rhIFN $\beta$-1a, only about $30 \%$ of the transgenic mice receiving this product showed antibodies against rhIFN $\beta-1 \mathrm{a}$. This is possibly explained by the absence of native epitopes in the covalent non-reducible aggregates as shown by Western blotting. Preservation of the native structure of the protein is a prerequisite for aggregates to break the tolerance of transgenic, immunetolerant mice (8). In addition to BABs, the wild-type mice formed NABs and immunological memory for the protein after 3-week administration of any of the rhIFN $\beta$-1a samples or Betaferon ${ }^{\circledR}$. This study confirms that wild-type animals cannot be used to study the immunogenicity of human therapeutic proteins, and immune-tolerant animal models are needed (47). In this paper, transgenic mouse models showed that protein aggregates are able to break the immune tolerance for rhIFN $\beta$. The potency of the aggregates to break tolerance not only depends on aggregate percentage but also largely on their physical properties such as degree of denaturation, molecular orientation and size. Moreover, we demonstrated that the breaking of immune tolerance for rhIFN $\beta$ in transgenic mice is characterized by the absence of NABs and immunological memory and thereby differs substantially from a classical T-cell-dependent immune response.

\section{ACKNOWLEDGEMENTS}

This research was financially supported by the European Community under its 6th Framework (project NABINMS, contract number 018926). Biogen Idec Inc. is acknowledged for kindly providing test products. We thank Susan Goelz for her valuable suggestions and discussions.

Open Access This article is distributed under the terms of the Creative Commons Attribution Noncommercial License which permits any noncommercial use, distribution, and reproduction in any medium, provided the original author(s) and source are credited.

\section{REFERENCES}

1. Schellekens H. Bioequivalence and the immunogenicity of biopharmaceuticals. Nat Rev Drug Discov. 2002;1:457-62.

2. Antonelli G. Reflections on the immunogenicity of therapeutic proteins. Clin Microbiol Infect. 2008;14:731-3.

3. Porter S. Human immune response to recombinant human proteins. J Pharm Sci. 2001;90:1-11.

4. Casadevall N, Nataf J, Viron B, Kolta A, Kiladjian J-J, MartinDupont $\mathrm{P}$, et al. Pure red-cell aplasia and antierythropoietin 
antibodies in patients treated with recombinant erythropoietin. N Engl J Med. 2002;346:469-75.

5. Sorensen PS. Review: neutralizing antibodies against interferonbeta. Ther Adv Neurol Disord. 2008;1:125-41.

6. Bertolotto A, Deisenhammer F, Gallo P, Sorensen PS. Immunogenicity of interferon beta: differences among products. J Neurol. 2004;251 Suppl 2:II15-24.

7. Runkel L, Meier W, Pepinsky RB, Karpusas M, Whitty A, Kimball K, et al. Structural and functional differences between glycosylated and non-glycosylated forms of human interferon-beta (IFN-beta). Pharm Res. 1998;15:641-9.

8. Hermeling S, Aranha L, Damen JMA, Slijper M, Schellekens $\mathrm{H}$, Crommelin DJA, et al. Structural characterization and immunogenicity in wild-type and immune tolerant mice of degraded recombinant human interferon alpha2b. Pharm Res. 2005;22:1997-2006

9. Fradkin AH, Carpenter JF, Randolph TW. Immunogenicity of aggregates of recombinant human growth hormone in mouse models. J Pharm Sci. 2009;98:3247-64.

10. Hermeling S, Schellekens H, Maas C, Gebbink MFBG, Crommelin DJA, Jiskoot W. Antibody response to aggregated human interferon alpha2b in wild-type and transgenic immune tolerant mice depends on type and level of aggregation. J Pharm Sci. 2006;95:1084-96

11. Rosenberg AS. Effects of protein aggregates: an immunologic perspective. AAPS J. 2006;8:E501-507.

12. Ottesen JL, Nilsson P, Jami J, Weilguny D, Dührkop M, Bucchini $\mathrm{D}$, et al. The potential immunogenicity of human insulin and insulin analogues evaluated in a transgenic mouse model. Diabetologia. 1994;37:1178-85.

13. Braun A, Kwee L, Labow MA, Alsenz J. Protein aggregates seem to play a key role among the parameters influencing the antigenicity of interferon alpha (IFN-alpha) in normal and transgenic mice. Pharm Res. 1997;14:1472-8.

14. Marini JC. Cell Cooperation in the antibody response. In: Male D, Brostoff J, Roth DB, Roitt I, editors. Immunology, vol. 9. Philadelphia: Elsevier Limited; 2006. p. 163-80.

15. Perini P, Facchinetti A, Bulian P, Massaro AR, De Pascalis D, Bertolotto A, et al. Interferon-beta (INF-beta) antibodies in interferon-betala- and interferon-betalb-treated multiple sclerosis patients. Prevalence, kinetics, cross-reactivity, and factors enhancing interferon-beta immunogenicity in vivo. Eur Cytokine Netw. 2001;12:56-61.

16. Bartelds GM, Wijbrandts CA, Nurmohamed MT, Stapel SO, Lems WF, Aarden L, et al. Anti-infliximab and anti-adalimumab antibodies in relation to response to adalimumab in infliximab switchers and anti-TNF naive patients: a cohort study. Ann Rheum Dis. 2010;69:817-21.

17. van Beers MMC, Sauerborn M, Gilli F, Hermeling S, Schellekens $\mathrm{H}$, Jiskoot W. Hybrid transgenic immune tolerant mouse model for assessing the breaking of $\mathrm{B}$ cell tolerance by human interferon beta. J Immunol Methods. 2010;352:32-7.

18. FDA. Center for Drug Evaluation and Research. Drugs@FDA online database. Label Information 2007 AVONEX BLA no. 103628. http://www.accessdata.fda.gov/drugsatfda_docs/label/ 2007/103628s5115lbl.pdf (accessed 01/22/10).

19. Gill SC, von Hippel PH. Calculation of protein extinction coefficients from amino acid sequence data. Anal Biochem. 1989;182:319-26.

20. Hermeling S, Jiskoot W, Crommelin DJA, Bornæs C, Schellekens H. Development of a transgenic mouse model immune tolerant for human interferon beta. Pharm Res. 2005;22:847-51.

21. Gilli F, van Beers M, Marnetto F, Jiskoot W, Bertolotto A, Schellekens H. Development of a bioassay for quantification of neutralising antibodies against human interferon-beta in mouse sera. J Immunol Methods. 2008;336:119-26.
22. Aitken A, Learmonth MP. Protein Determination by UV Absorption. In: Walker JM, editor. The protein protocols handbook. Totowa: Humana Press Inc.; 2002. p. 3-6.

23. Kueltzo LA, Middaugh CR. Ultraviolet Absorption Spectroscopy. In: Jiskoot W, Crommelin DJA, editors. Methods for structural analysis of protein pharmaceuticals, vol. III. Arlington: AAPS; 2005. p. 1-25.

24. Utsumi J, Yamazaki S, Kawaguchi K, Kimura S, Shimizu H. Stability of human interferon-beta 1: oligomeric human interferon-beta 1 is inactive but is reactivated by monomerization. Biochim Biophys Acta. 1989;998:167-72.

25. Karpusas M, Nolte M, Benton CB, Meier W, Lipscomb WN, Goelz S. The crystal structure of human interferon-beta at 2.2- $\AA$ resolution. Proc Natl Acad Sci USA. 1997;94:11813-8.

26. Demeester J, de Smedt SS, Sanders NN, Haustraete J. Light Scattering. In: Jiskoot W, Crommelin DJA, editors. Methods for structural analysis of protein pharmaceuticals, vol. III. Arlington: AAPS; 2005. p. 245-75.

27. Philo JS. A critical review of methods for size characterization of non-particulate protein aggregates. Curr Pharm Biotechnol. 2009; 10:359-72.

28. Karpusas M, Whitty A, Runkel L, Hochman P. The structure of human interferon- $\beta$ : implications for activity. Cell Mol Life Sci. 1998;54:1203-16.

29. Runkel L, deDios C, Karpusas M, Betzenhauser M, Muldowney C, Zafari M, et al. Systematic mutational mapping of sites on human interferon-beta-la that are important for receptor binding and functional activity. Biochemistry. 2000;39:2538-51.

30. Qiu W, Li T, Zhang L, Yang Y, Kao Y-T, Wang L, et al. Ultrafast quenching of tryptophan fluorescence in proteins: interresidue and intrahelical electron transfer. Chem Phys. 2008;350:154-64.

31. Chen Y, Barkley MD. Toward understanding tryptophan fluorescence in proteins. Biochemistry. 1998;37:9976-82.

32. Fan H, Ralston J, Dibiase M, Faulkner E, Middaugh CR. Solution behavior of IFN-beta-la: an empirical phase diagram based approach. J Pharm Sci. 2005;94:1893-911.

33. Hawe A, Friess W. Stabilization of a hydrophobic recombinant cytokine by human serum albumin. J Pharm Sci. 2007;96:298799.

34. Lin LS, Kunitani MG, Hora MS. Interferon-beta-lb (Betaseron): A model for hydrophobic therapeutic proteins. In: Pearlman R, Wang JY, editors. Formulation, characterization, and stability of protein drugs: case histories, vol. 9. New York: Plenum; 1996. p. 275-301.

35. Hawe A, Friess W. Development of HSA-free formulations for a hydrophobic cytokine with improved stability. Eur J Pharm Biopharm. 2008;68:169-82.

36. Li S, Nguyen TH, Schoneich C, Borchardt RT. Aggregation and precipitation of human relaxin induced by metal-catalyzed oxidation. Biochemistry. 1995;34:5762-72.

37. Walker JM. SDS Polyacrylamide gel electrophoresis of proteins. In: Walker JM, editor. The protein protocols handbook. Totowa: Humana Press Inc.; 2002. p. 61-7.

38. Conradt HS, Egge H, Peter-Katalinic J, Reiser W, Siklosi T, Schaper K. Structure of the carbohydrate moiety of human interferon-beta secreted by a recombinant Chinese hamster ovary cell line. J Biol Chem. 1987;262:14600-5.

39. González-Fernández Á, Faro J, Fernández C. Immune responses to polysaccharides: lessons from humans and mice. Vaccine. 2008;26:292-300.

40. Herndon RM, Rudick RA, Munschauer III FE, Mass MK, Salazar AM, Coats ME, et al. Eight-year immunogenicity and safety of interferon beta-la-Avonex treatment in patients with multiple sclerosis. Mult Scler. 2005;11:409-19.

41. Millonig A, Rudzki D, Holzl M, Ehling R, Gneiss C, Kunz B, et al. High-dose intravenous interferon beta in patients with 
neutralizing antibodies (HINABS): a pilot study. Mult Scler. 2009;15:977-83.

42. Rice GPA, Paszner B, Oger J, Lesaux J, Paty D, Ebers G. The evolution of neutralizing antibodies in multiple sclerosis patients treated with interferon beta-1b. Neurology. 1999;52: 1277-9.

43. Malucchi S, Capobianco M, Gilli F, Marnetto F, Caldano M, Sala A, et al. Fate of multiple sclerosis patients positive for neutralising antibodies towards interferon beta shifted to alternative treatments. Neurol Sci. 2005;26 Suppl 4:s213-4.

44. Bellomi F, Scagnolari C, Tomassini V, Gasperini C, Paolillo A, Pozzilli $\mathrm{C}$, et al. Fate of neutralizing and binding antibodies to IFN beta in MS patients treated with IFN beta for 6 years. J Neurol Sci. 2003;215:3-8.

45. Sorensen PS, Koch-Henriksen N, Ross C, Glemmesen KM, Bendtzen K. Danish multiple sclerosis study group. Appearance and disappearance of neutralizing antibodies during interferonbeta therapy. Neurology. 2005;65:33-9.

46. Sorensen PS, Koch-Henriksen N, Flachs EM, Bendtzen K. Is the treatment effect of IFN-beta restored after the disappearance of neutralizing antibodies? Mult Scler. 2008;14:837-42.

47. Sauerborn M, Brinks V, Jiskoot W, Schellekens H. Immunological mechanism underlying the immune response to recombinant human protein therapeutics. Trends Pharmacol Sci. 2010;31:53-9. 